\section{Is the macromolecular protein complex (MPC) a marker for oxidative stress in diabetes mellitus?}

To the Editor: It is generally recognized that diabetes mellitus is associated with accelerated atherosclerosis and increased incidence of cardiovascular disease [1]. A state of hypercoagulability in diabetes mellitus is manifested by increased plasma fibrinogen concentrations and inhibition of fibrinolysis [2]. In recent years attention has been focused on the role of inflammation and its association with oxidative stress in cardiovascular disease. Although a link between oxidative stress and hypercoagulability has been suggested previously, no direct evidence has yet been available [3]. In 1995 we reported the existence of increased quantities of a macromolecular protein complex (MPC) in plasma of patients with Type I (insulin-dependent) diabetes mellitus [4]. A characteristic feature of MPC is that although it is not clottable with thrombin, it becomes effectively incorporated into fibrin clot thus increasing clot mass and making it resistant to fibrinolytic degradation. These two features of MPC can account for hypercoagulability associated with diabetes. However, there was no explanation of the mechanism by which MPC is generated in blood circulation. Subsequently, it was shown that MPC contains a triglyceride (TG)-rich component that could be detected in washed fibrin clots obtained from plasma of Type I diabetic patients [5]. Determination of the protein-to-TG ratio in MPC indicated that this complex contained not only very low density lipoprotein (VLDL) but also other plasma protein(s).

Preliminary analysis of MPC showed the presence of a protein reacting with a specific antibody to human fibrinogen. This finding prompted us to carry out a series of experiments that could explain a possible mechanism of MPC formation. It has been previously observed that when a solution of purified fibrinogen is exposed to a hydroxyl radical generating environment, an insoluble polymer containing dityrosine crosslinks is formed. We have subsequently found that such a polymer is remarkably resistant to proteolytic degradation. This resistance can be explained in terms of a carbon-carbon bond between phenolic rings in dityrosine which, by contrast to the peptide bond, is not hydrolysed by proteolytic enzymes. In the following experiment we showed that when plasma is exposed to hydroxyl radicals, a polymer similar to that obtained with purified fibrinogen is formed. Pooled plasma obtained from five healthy subjects was dialysed to remove the chelating anticoagulant. Next, the plasma was mixed with ascorbic acid and cupric chloride at final concentrations of $12 \mathrm{mmol} / \mathrm{l}$ and $3 \mathrm{mmol} / \mathrm{l}$, respectively. A fibrous precipitate which formed within 5 min standing at room temp was centrifuged, then washed three times with saline, suspended in one $\mathrm{ml}$ of Tris buffer $(\mathrm{pH} 7.4)$ containing $5 \mu \mathrm{g}$ of chymotrypsin and incubated for $10 \mathrm{~min}$ at $37^{\circ} \mathrm{C}$, followed by $5 \mu \mathrm{g}$ of soybean trypsin inhibitor. The resulting opalescent solution containing $22 \mathrm{mg} / \mathrm{ml}$ of protein and $2 \mathrm{mg} / \mathrm{ml}$ of TG, was then subjected to gel exclusion chromatography using Sepharose 6B as previously described [4]. The opalescent fraction emerged with the void volume of the column, as did MPC isolated from diabetic plasma. This fraction contained $340 \mu \mathrm{g} /$ $\mathrm{ml}$ of protein and $120 \mu \mathrm{g} / \mathrm{ml}$ of TG, reacted positively with human anti-fibrinogen antibody as tested in the ELISA system and was effectively incorporated into the fibrin clot. Results of preliminary analysis of the in vitro prepared complex and of MPC isolated from plasma of healthy subjects and from five Type I diabetic patients are shown in Table 1.

The striking similarity of the product obtained in vitro to MPC isolated from diabetic plasma suggests that the latter
Table 1. The content of protein, triglycerides, dityrosine (diTyr) and dihydroxyphenylalanine (DOPA) in a macromolecular protein complex (MPC) obtained from plasma of healthy subjects and Type I diabetic patients, and in an in vitro prepared complex (IVPC)

\begin{tabular}{|c|c|c|c|c|}
\hline \multirow{2}{*}{$\begin{array}{l}\text { MPC } \\
\text { source }\end{array}$} & \multirow{2}{*}{$\begin{array}{l}\text { Protein } \\
\mu \mathrm{g} / \mathrm{ml}\end{array}$} & \multirow{2}{*}{$\begin{array}{l}\text { Triglyce- } \\
\text { rides } \\
\mu \mathrm{g} / \mathrm{ml}\end{array}$} & $\operatorname{diTyr}^{\mathrm{a}}$ & $\mathrm{DOPA}^{\mathrm{a}}$ \\
\hline & & & \multicolumn{2}{|c|}{$\mathrm{mmol} / \mathrm{mol} \mathrm{Tyr}$} \\
\hline Healthy subjects' & $85 \pm 7$ & $36 \pm 4$ & traces & $0.437 \pm 0.041$ \\
\hline IDDM patients & $320 \pm 12$ & $640 \pm 12$ & traces & $1.265 \pm 0.063$ \\
\hline IVPC & $340 \pm 10$ & $120 \pm 8$ & 0 & $1.555 \pm 0.117$ \\
\hline
\end{tabular}

${ }^{a}$ Determined by HPLC analysis after acid hydrolysis of samples [6]

could be formed in vivo as a result of oxidative crosslinking of fibrinogen with a TG-rich lipoprotein. The fact that only traces of dityrosine as compared to significant amounts of dihydroxyphenylalanine were detected in all samples, suggests that isodityrosine rather than dityrosine crosslinks are present in MPC. However, in view of a great reactivity of hydroxyl radicals, it is possible that in vivo formation of MPC involves other plasma proteins, notably serum albumin. Oxidative damage to such proteins could result in their partial unfolding and exposure of internal hydrophobic domains followed by the formation of aggregates resistant to proteolytic degradation [7]. Of note, a macromolecular protein similar to MPC, termed advanced oxidation protein product (AOPP), was shown to be increased in patients with uremia [8]. We conclude that the presence of MPC in human plasma could be a marker of oxidative stress in Type I diabetes.

B. Lipinski, I. Lipinska, Y. Kato

\section{References}

1. Haffner SM (2000) Coronary heart disease in patients with diabetes. (2000) N Eng J Med 342: 1040-1042

2. Ganda OP, Arkin CF (1992) Hyperfibrinogenemia: An important risk factor for vascular complication in diabetes. Diabetes Care 15: 1245-1250

3. Ceriello A (1999) Hyperglycaemia: the bridge between nonenzymatic glycation and oxidative stress in the pathogenesis of diabetic complications. Diabetes Nutr Metab 12: 42-46

4. Lipinski B, Federman SM, Krolewski AS (1995) Plasma macromolecular protein complex: Interaction with fibrin and fibrinolysis. Thromb Res 78: 461-465

5. Lipinski B (1995) Fibrin clot triglycerides and fibrinolysis. Fibrinolysis 9: 368

6. Fu S, Dean R, Southan M, Truscott R (1998) The hydroxyl radical in lens nuclear cataractogenesis. J Biol Chem 273: 28603-28609

7. Davies KJA (2001) Degradation of oxidized proteins by the 20S proteasome. Biochimie 83: 301-310

8. Witko-Sarsat V, Friedlander M, Capeillere-Blandin C et al. (1996) Advanced oxidation protein products as a novel marker of oxidative stress in uremia. Kidney Int 49: 1304-1313

Corresponding author: B. Lipinski MD, Department of Genetics and Epidemiology, Joslin Diabetes Center, One Joslin Place, Boston, MA 02215, USA 